\title{
Comparison of Arterial and Arterialized Capillary Blood in Infants with Respiratory Distress
}

\author{
ANN BANISTER* \\ From the Special Care Baby Unit, North Staffordshire Maternity Hospital, Stoke-on-Trent
}

Arterial sampling for monitoring blood gases and $p \mathrm{H}$ in respiratory distress of the newborn is only practised in a few centres in Britain. For control of acid base balance most paediatricians rely on capillary samples, which do not require experienced medical staff for collection. Micro-equipment for measuring $\mathrm{Po}_{2}$ in capillary samples is now commercially available. This study was planned to assess the practical value of capillary readings. One previous study in sick newborns has been reported (Gandy et al., 1964), but this was in babies of $2000 \mathrm{~g}$. or more.

\section{Material and Methods}

Newborn babies suffering from respiratory distress, in whom umbilical artery catheters were inserted for control of therapy, were studied. Details are given in Table I. The age at sampling ranged from 3 to 95 hours, the majority of samples being taken before 48 hours. Capillary samples were collected from a warmed heel (Siggaard-Andersen et al., 1960). Immediately afterwards arterial blood was withdrawn into a heparinized glass syringe, the first $0.5 \mathrm{ml}$. blood being discarded to avoid dilution with the heparin-saline solution filling the umbilical artery catheter between sampling. Samples were analysed in duplicate either immediately or within an hour after storage in iced water (Siggaard-Andersen, 1961; Johnstone, 1966). $\mathrm{pH}, \mathrm{PCO}_{2}$, and base deficit were measured by the method of Siggaard-Andersen et al. (1960) and SiggaardAndersen and Engel (1960), using Radiometer equipment. When a micro-oxygen electrode became available (Radiometer E5044) comparative $\mathrm{Po}_{2}$ measurements were also made. The $t$ test was applied to assess the significance of arterial-capillary differences.

\section{Results}

Results are given in Table II, and in Fig. 1 to 4 . There was good correlation between arterial and capillary values for $p \mathrm{H}$ measurements throughout.

Received April 22, 1969.

^Present address: Alder Hey Children's Hospital, Liverpool.
However, $\mathrm{PCO}_{2}, \mathrm{Po}_{2}$, and base deficit were poorly correlated, the differences being significant. Capillary blood tended to have a higher $\mathbf{P C O}_{2}$ and a lower $\mathrm{Po}_{2}$ and base deficit. Age, birthweight, and maturity did not influence these results, but the state of the puncture site was important. Feet that were originally warm and where blood flowed freely after puncture were judged to have a good circulation. The presence of oedema of the foot was graded as slight or marked. $\mathbf{P C O}_{2}$ correlation was poor whatever the state of the foot, though variation was least with a good peripheral circulation. The presence of oedema was the important factor in giving unreliable capillary base deficit measurements. In the absence of oedema, whatever the state of the peripheral circulation, there was close correlation with arterial readings. The number of $\mathrm{Po}_{2}$ readings was too small for such further analysis.

\section{TABLE I}

Details of Babies Studied.

\begin{tabular}{|c|c|c|c|}
\hline $\begin{array}{l}\text { No. of } \\
\text { Readings }\end{array}$ & $\begin{array}{l}\text { Birthweight } \\
\quad(\mathrm{g} .)\end{array}$ & $\begin{array}{l}\text { Gestation } \\
\quad(w k .)\end{array}$ & Diagncsis ${ }^{\star}$ \\
\hline 3 & 1340 & 33 & RDS; twin \\
\hline 3 & 1360 & 33 & RDS; twin \\
\hline 1 & 1360 & 30 & RDS \\
\hline 6 & 1420 & 32 & RDS \\
\hline 4 & 1720 & 34 & $\begin{array}{l}\text { RDS; accidental } \\
\text { haemorrhage; CS }\end{array}$ \\
\hline 3 & 1790 & 34 & RDS; severe PET; CS \\
\hline 1 & 1930 & $?$ & RDS \\
\hline 4 & 2360 & 36 & RDS \\
\hline 1 & 2470 & 34 & $\begin{array}{l}\text { RDS; accidental } \\
\text { haemorrhage; CS }\end{array}$ \\
\hline 10 & 2470 & 36 & $\begin{array}{l}\text { RDS; placenta praevia; } \\
\text { CS }\end{array}$ \\
\hline 4 & 2040 & 32 & $\begin{array}{l}\text { Bronchopneumonia at } \\
36 \text { hours }\end{array}$ \\
\hline 3 & 3630 & 37 & $\begin{array}{l}\text { Choanal atresia; } \\
\text { diabetic mother; CS }\end{array}$ \\
\hline 2 & 3580 & 43 & Meconium aspiration \\
\hline
\end{tabular}

^ RDS, respiratory distress syndrome; PET, pre-eclamptic toxaemia; CS, caesarean section. 
TABLE II

Results

\begin{tabular}{|c|c|c|c|c|c|c|c|c|}
\hline & & & & & $\begin{array}{c}\text { No. of } \\
\text { Observations }\end{array}$ & $\begin{array}{c}\text { Mean } \\
\text { Difference* }\end{array}$ & SD & $\mathbf{p}$ \\
\hline All measurements & $\ldots$ & $\ldots$ & $\ldots$ & $\begin{array}{c}\mathrm{pH} \\
\mathrm{PCO}_{2} \\
\text { Base deficit } \\
\mathrm{Po}_{2}\end{array}$ & $\begin{array}{l}45 \\
45 \\
45 \\
12\end{array}$ & $\begin{array}{l}+0.007 \\
-8.29 \mathrm{~mm} . \mathrm{Hg} \\
+1.31 \mathrm{mEq} \\
+6.25 \mathrm{~mm} . \mathrm{Hg}\end{array}$ & $\begin{array}{l}0 \cdot 039 \\
16 \cdot 7 \\
2 \cdot 36 \\
4 \cdot 8\end{array}$ & $\begin{array}{l}>0.2 \\
<0.005 \\
<0.001 \\
<0.001\end{array}$ \\
\hline $\begin{array}{l}\text { Good circulation } \\
\text { Poor circulation } \\
\text { Slight oedema } \\
\text { Marked oedema }\end{array}$ & $\begin{array}{l}\cdots \\
\cdots \\
\cdots \\
\cdots\end{array}$ & $\begin{array}{l}\cdots \\
\cdots \\
\cdots \\
\cdots\end{array}$ & $\begin{array}{l}\cdots \\
\cdots \\
\cdots \\
\cdots\end{array}$ & \begin{tabular}{l}
\multicolumn{1}{c}{$\mathrm{PCO}_{2}$} \\
Base deficit \\
Base deficit \\
Base deficit \\
Base deficit
\end{tabular} & $\begin{array}{r}15 \\
15 \\
12 \\
8 \\
10\end{array}$ & $\begin{array}{l}-5.47 \mathrm{~mm} . \mathrm{Hg} \\
+0.53 \mathrm{mEq} \\
+0.42 \mathrm{mEq} \\
+2.5 \mathrm{mEq} \\
+2.8 \mathrm{mEq}\end{array}$ & $\begin{array}{l}7 \cdot 1 \\
1 \cdot 9 \\
0 \cdot 9 \\
3 \cdot 32 \\
2 \cdot 39\end{array}$ & $\begin{array}{l}<0.01 \\
>0.3 \\
>0.1 \\
>0.05 \\
<0.005\end{array}$ \\
\hline
\end{tabular}

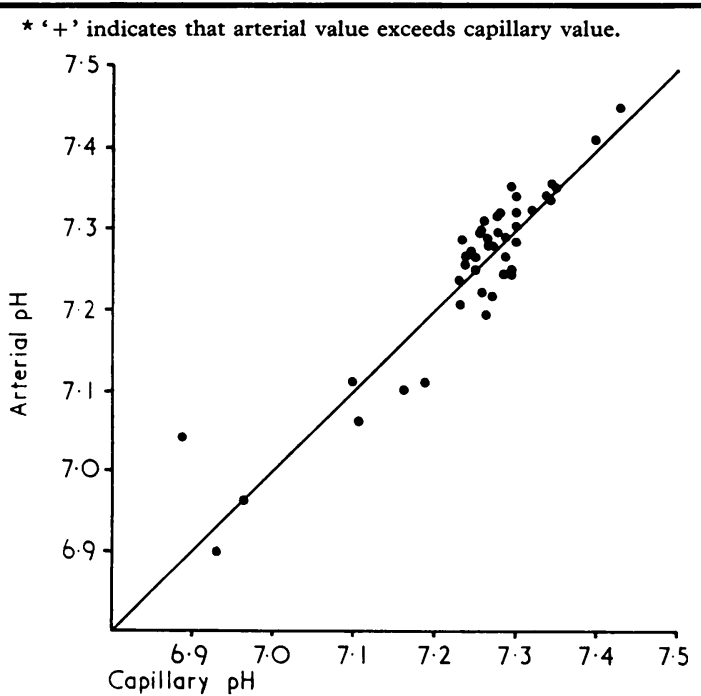

FIG. 1.-Comparison between arterial and capillary $\mathrm{pH}$.
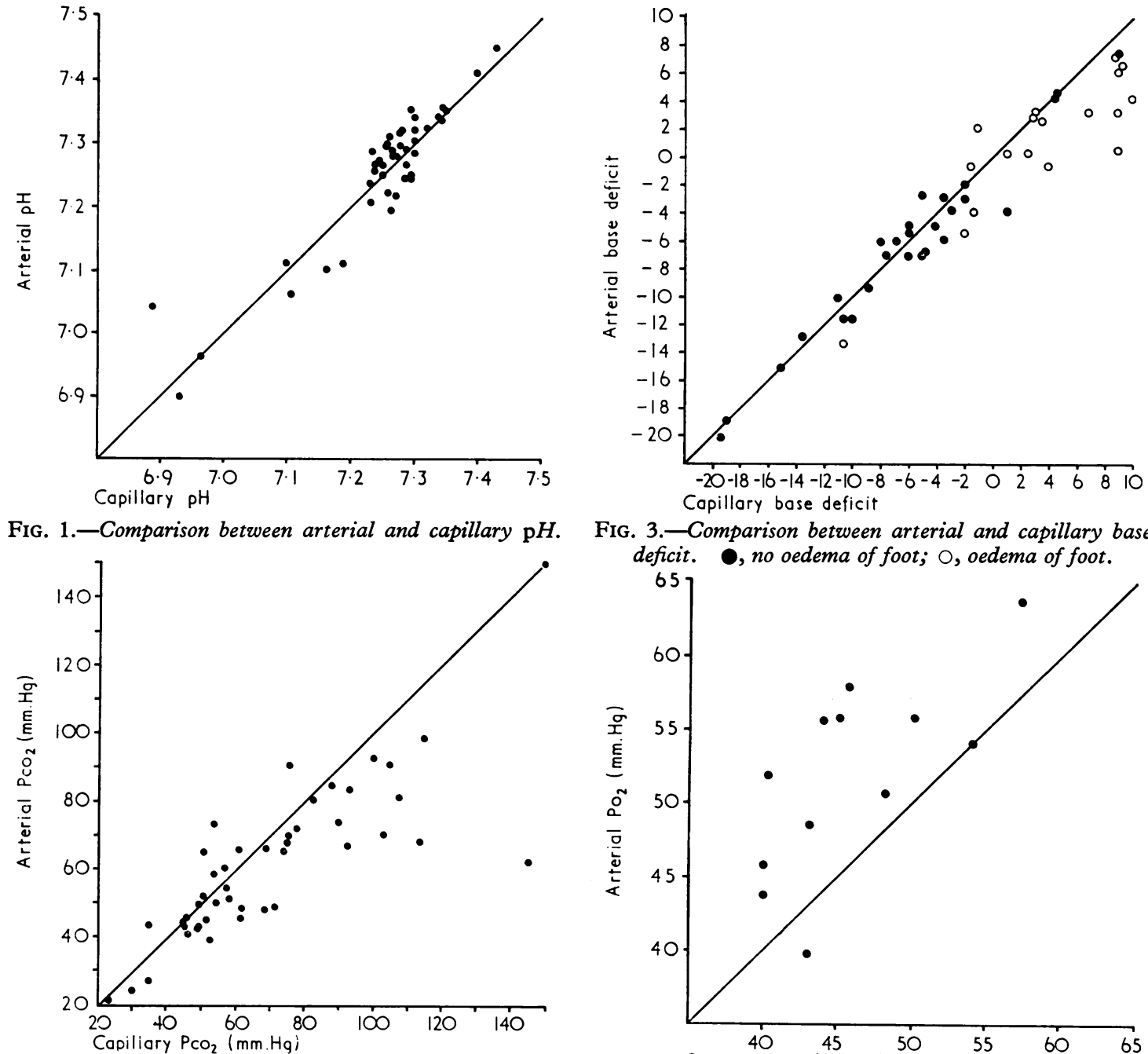

Fig. 3.-Comparison between arterial and capillary base deficit. @, no oedema of foot; $\bigcirc$, oedema of foot.

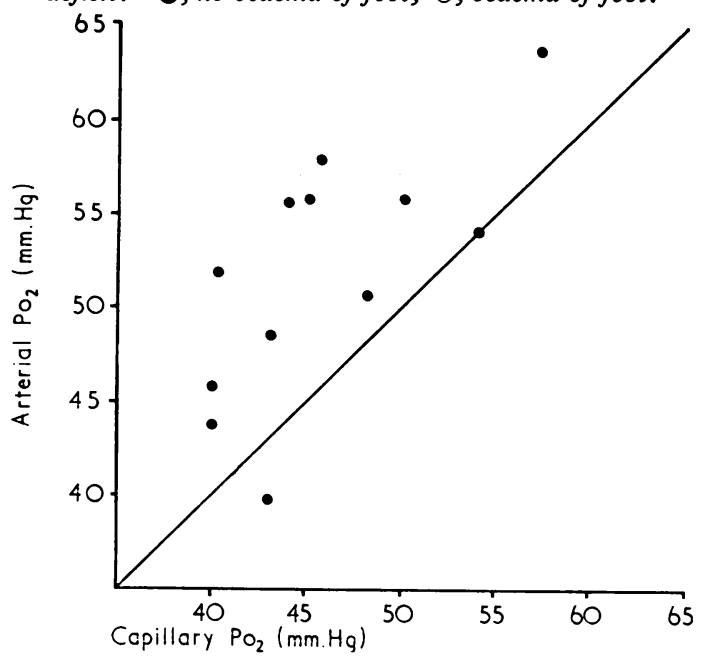

Fig. 4.-Comparison of arterial and capillary $\mathrm{Po}_{2}$.

FIG. 2.-Comparison between arterial and capillary $\mathrm{PCO}_{2}$. 


\section{Discussion}

This study in newborn babies suffering from respiratory distress has shown that capillary $\mathrm{Po}_{2}$ and $\mathrm{PCO}_{2}$ results from a heel prick are unreliable for use as a guide to oxygen therapy or the need for artificial ventilation. The arterialcapillary differences are greater than could arise by chance, and the variation of capillary results is wide. The capillary base deficit is a reliable guide to the correction of metabolic acidosis only in the absence of oedema at the puncture site. As many premature babies, and especially those suffering from respiratory distress, develop oedema, the usefulness of capillary samples in sick newborns is limited.

Studies in adults have shown the importance of careful arterialization of the puncture site for collection of capillary blood (Koch, 1965). Results from correctly warmed sites may be unreliable, especially where the peripheral circulation is poor, though the ear lobe is a more reliable site than the thumb (Koch, 1965, 1968; Laughlin, McDonald, and Bedell, 1964; MacIntyre, Norman, and Smith, 1968; Worth, 1965). Satisfactory $p \mathrm{H}, \mathrm{PcO}_{2}$, and base deficit readings in normal newborns cannot be obtained from capillary blood at birth. Gandy et al. (1964) found good correlation with results from arterial blood after 3 hours, and Koch and Wendel (1967) only after 48 hours of life. In healthy prematures Thomsen (1964) found poor correlation, though the ages of the babies were not stated. Koch and Wendel (1967) found capillary $\mathrm{Po}_{2}$ unreliable in normal neonates.

Gandy et al. (1964) studied 40 sick babies, all weighing $2000 \mathrm{~g}$. or more, of whom 18 had respiratory distress syndrome, the others having suffered severe fetal distress, or having severe cyanotic congenital heart disease. The 46 readings in these 40 babies were analysed together. Correlation between arterial and capillary $p \mathrm{H}$ and $\mathrm{PCO}_{2}$ readings was not as good as in normal newborns, but the differences were still much less than those found in the present study. This may be due to the difference in maturity in the two groups. They found good correlation throughout for base deficit. This contrasts with the present findings, where there was poor correlation for base deficit in the overall figures, though the error was shown to arise from samples from oedematous feet. All these studies in babies have used blood from a heel stab. Desai et al. (1967), in older newborns having artificial ventilation for tetanus, used capillary samples from the scalp, and found excellent correlation of $\mathrm{Po}_{2}$ with temporal artery samples. It is possible that this site might give more reliable results in respiratory distress than the heel.

\section{Summary}

Comparison was made of 45 capillary heel prick and arterial samples in 13 newborn babies with respiratory distress. Good correlation was found between arterial and capillary $p \mathrm{H}$. Both capillary $\mathbf{P C O}_{2}$ and $\mathrm{Po}_{2}$ were unreliable. Base deficit readings were reliable whatever the state of the peripheral circulation unless there was oedema of the feet.

I am grateful to Dr. J. Dathan and Dr. D. ThursbyPelham for permission to study their patients; to Miss R. Haslock, biochemist, and her staff for some of the estimations; to the nursing staff; and to Dr. R. S. Jones for his criticism and advice in the preparation of this paper.

\section{REFERENCES}

Desai, S. D., Holloway, R., Thambiran, A. K., and Wesley, A. G. (1967). A comparison between arterial and arterialized capillary blood in infants. S. Afr. med. F., 41, 13.

Gandy, G., Grann, L., Cunningham, N., Adamsons, K., Jr., and James, L. S. (1964). The validity of $\mathrm{pH}$ and $\mathrm{PCO}_{2}$ measurements in capillary samples in sick and healthy newborn infants. Pediatrics, 34, 192.

Johnstone, J. H. (1966). Measurement of arterial and capillary blood oxygen tension. f. clin. Path., 19, 357.

Koch, G. (1965). Comparison of carbon dioxide tension, $\mathrm{pH}$ and standard bicarbonate in capillary blood and in arterial blood, with special respect to relations in patients with impaired cardiovascular and pulmonary function and during exercise. Scand. F. clin. Lab. Invest., 17, 223.

- (1968). The validity of $\mathrm{pO}_{2}$ measurement in capillary blood as a substitute for arterial $\mathrm{pO}_{2}$. ibid., 21,10 .

tension, standard bicarbonate and oxygen tension in capillary blood and in arterial blood during the neonatal period. Acta paediat. (Scand.), 56, 10.

Laughlin, D. E., McDonald, J. S., and Bedell, G. N. (1964). A microtechnique for measurement of $\mathrm{PO}_{2}$ in 'arterialized' earlobe blood. F. Lab. clin. Med., 64, 330.

MacIntyre, J., Norman, J. N., and Smith, G. (1968). Use of capillary blood in measurement of arterial $\mathrm{pO}_{2}$. Brit. med. $\mathcal{F}$., 3,640 .

Siggaard-Andersen, O. (1961). Sampling and storing of blood for determination of acid-base status. Scand. F. clin. Lab. Invest., 13, 196.

, and Engel, K. (1960). A new acid-base nomogram. ibid., $12,177$.

, - Jørgensen, K., and Astrup, P. (1960). A micro method for determination of $\mathrm{pH}$, carbon dioxide tension, base excess and standard bicarbonate in capillary blood. ibid., 12, 172.

Thomsen, A. (1964). Arterial blood sampling in small infants. Acta paediat. (Uppsala), 53, 237.

Worth, G. (1965). Blood-samples from ear-lobe puncture. Lancet, 2, 907.

Correspondence to Dr. A. Banister, Alder Hey Children's Hospital, Eaton Road, Liverpool 12. 